\title{
Community Participation in Sanitation Kampung Program, Surakarta
}

\author{
Anak Agung Alit Kirti Estuti Narendra Putri'), Hermanu Joebagio²), Dono Indarto3) \\ ${ }^{1)}$ Masters Program in Public Health, Sebelas Maret University \\ 2)Faculty of Teaching and Educational Sciences, Sebelas Maret University \\ 3)Faculty of Medicine, Sebelas Maret University
}

\begin{abstract}
Background: Indonesia ranks third in the world in the number of people with limited access to sanitation. Surakarta municipality government in collaboration with local drinking water supplier (PDAM) operate Indonesian Urban Water, Sanitation and Hygiene (IUWASH) to overcome sanitation problems in the form of Sanitation Kampung Program in Semanggi Village, Surakarta. This study aimed to review community participation in Sanitation Kampung Program, Semanggi Village.

Subjects and Method: This was a qualitative study conducted at RW 23, Semanggi Village, Pasar Kliwon subdistrict, Surakarta, Central Java. Informants were selected purposively for this study comprising 12 community members as key informants, 2 community leaders, head of Sanitation Kampung Program, and 1 environmental health expert as supporting informants. The data were collected by in-depth interview, focus group discussion, and document review. Data credibility was checked by triangulation. The data were analyzed by content analysis.

Results: At the beginning of Sanitation Kampung Program planning there were some pros and cons from the community. Some of the community accepted the program but some others refused it due to negative perception that Sanitation Kampung Program would cause bad smell and pollute well water. In order to overcome community refusal toward Sanitation Kampung Program, IUWASH, Surakarta municipality government, and community leaders, carried out socialization, community approach, and study tour to other places. In the end, the community accepted Sanitation Kampung Program. Community members participated the program by providing support for water and sanitation facility development. Community members made use of the water and sanitation facility for daily activities. They also maintained the water and sanitation facility.

Conclusion: By developing good and trustable collaboration, community participate in Sanitation Kampung Program from planning, developing, using, and maintenance of the water and sanitation facility.
\end{abstract}

Keywords: water, sanitation, community, participation, program

\section{Correspondence:}

Anak Agung Alit Kirti Estuti Narendra Putri. Masters Program in Public Health, Sebelas Maret University, Jl. Ir. Sutami 36 A, Surakarta 57126, Central Java. Email: kirtiestuti@gmail.com. Mobile: +6285643231616 .

\section{BACKGROUND}

Environmental health problem is a global issue. Most of the poor and middle income countries have inadequate access to decent water and sanitation (Gon et al., 2016). The problem occurs in almost all continents namely South East Asia, East Asia and Asia Pacific, Latin America and Caribia, East
Europe, Middle east and Africa (Jeuland et al., 2013). World Health Organization (WHO) estimates about 2.6 billion of the world populations live with inadequate sanitation and the risk of poor environmental health (Engel and Susilo, 2014). Environmental health turned to be priority issue which was included in global agenda 
Journal of Health Promotion and Behavior (2017), 2(3): 257-271

https://doi.org/thejhpb.2016.02.03.06

through Millenium Development Goals (MDGs) that has ended in 2015 and then it proceeds in Sustainable Development Goals (SDGs). Within SDGs agenda, sanitation and clean water availability is the sixth goal of international health agenda with the main target is water feasibility, sanitation, and cleanliness (WHO, 2015).

Indonesia ranks third in number of population with limited access to sanitation (UNICEF, 2012). The data showed that in Indonesia about 116 million population still lack adequate sanitation, 41 million people still defecate in the open air, and $17 \%$ of urban slums inhabitants defecate without using latrine (Kemenkes RI, 2011).

Provinces in Indonesia with the lowest proportion of households without access to drinking water are Riau Islands (24.0\%), East Kalimantan (35.2\%), Bangka Belitung (44.3)\%, Riau (45.5\%), and Papua (45.7\%). Five provinces with the highest proportion of households with access to drinking water are North Maluku (75.3\%), Central Java (77.8\%), East Java (77.9\%), Special Region of Yogyakarta (81.7\%), and Bali (82.0\%) (Kemenkes RI, 2013).

Even Central Java is one of five provinces with the highest proportion of household with access to drinking water, only $77 \%$ of population who have access to feasible drinking water (Dinkes Jateng, 2014). The issue on access to clean water in urban area is generated by the condition of ground water which is no longer drinkable and public incapability to access water from drinking water company or purchase drinkable bottled water (Enralin dan Lubis, 2015).

Poor environmental sanitation may generate diseases to human (Cornburn and Hildebrand, 2015). Some studies proved that infectious diseases of the digestion system such as diarrhea, cholera, and helminthiasis are caused by the inadequate condition of sanitation and water (Cairncross et al., 2010; Echazu et al., 2015; Mengel, 2014; Taylor et al., 2015). Furthermore, the condition of water, sanitation, and environmental hygiene are also at risk to hinder children growth and development as the result of infectious diseases, stunting and anemia (Ngure et al., 2014). Since the impacts of environmental sanitation condition and water availability are very extensive, therefore environmental health is an important factor to concern about (Kandou and Lasut, 2010). Environmental health includes the availability of clean water, the use of toilet, waste water treatment, waste disposal, soil pollution (Kasnodiharjo and Elsi, 2013).

Many efforts have be performed to overcome sanitation problems in Indonesia (Trisnawati and Marsono, 2012; Kemenkes RI, 2016a). Sanitation facilities development program needs public participation. Public active involvement from the beginning after post construction stage, especially in using and maintaining the sanitation facilities, truly determines the program accomplishment.

All this time the sanitation facilities development by the government is considered merely as grant project, since it does not fully involve public participation. The planning process up to the development of sanitation facilities is often less accommodating public needs and wish (Sofyan et al., 2016).

In the area of Surakarta municipality there are community groups which are categorized as low income with limited access to sanitation and clean water. In sub-districts of Pasar Kliwon, Banjarsari, and Laweyan, Surakarta, a lot of people do not have access to clean tap water. One of the strategies to effectively overcome sanitation problems in several areas is by means of pilot project. Since 2014, Sura- 
karta municipality government and Surakarta Regional Drinking Water Company (PDAM) has been collaborating with Indonesia Urban Water, Sanitation dan Hygiene (IUWASH) to overcome sanitation problems in Surakarta through Sanitation Kampung Program in Semanggi village (IUWASH, 2014).

Sanitation Kampung Program is developed to give model for clean water supply and community based sanitation development in Indonesia. It is located in RW 23, Semanggi Village, Pasar Kliwon Subdistrict. Semanggi Village is one of slumps in Pasar Kliwon Sub-district, Surakarta. Sanitation Kampung Program has been proceeding for 3 years since it was launched for the first time. The most appropriate way to overcome environmental problems is by involving the entire society elements (French, 2007).

The study aimed to review community participation in Sanitation Kampung Program in Semanggi Village.

\section{SUBJECTS AND METHOD}

\section{Design of the Study}

The method used in the study was qualitative method by using participatory approach. The study was conducted in AprilJune 2017 in RW23 Semanggi Village, Pasar Kliwon Sub-dictrict, Surakarta. The area of RW 23 Semanggi Village is the location of Sanitation Kampung Program, that has been implemented since 2014 .

\section{Instruments of the Study}

Population of the study was community of RW23, Semanggi Village, Pasar Kliwon Sub-district, Surakarta. The study was conducted by using purposive sampling. There were 12 key informants who were community members of RW23, Semanggi Village. There were 4 supporting informants, including 2 community leaders, 1 head of KSM, and 1 environmental health specialist

\section{Data Collection Technique}

The data were collected by using in-depth interview, focused-group discussion, and documentation. In-depth interview and focused-group discussion were conducted to gain data on community perception toward Sanitation Kampung Program, community participation in Sanitation Kampung Program also the achievement as well as barriers of Kampung Sanitation Program in Semanggi Village.

The data of in-depth interview were obtained from 12 informants who were community members of RW23, Semanggi Village, whereas the data of FGD were gained from 2 community leaders, 1 head of KSM, and 1 environmental health specialist

In-depth interview was conducted in 15-30 minutes for each informant, whereas FGD was conducted in 90-12 minutes. The data were recorded by using voice recorder.

The study used observation technique to strengthen data. The observations included observation toward condition, management, utilization and maintenance of water and sanitation facilities in Sanitation Kampung Program. The documents used in the study were the community data of Semanggi Village and pictures of water and sanitation facilities. The study had been approved for its feasibility through letter of ethical feasibility No. 423/V/HREC/2017.

\section{Data Credibility Test}

Validity of the study was conducted by using credibility criteria and dependability. Credibility of the study was conducted by using member check and triangulation. Member check was conducted by giving data, analysis category, discussion and conclusion on members of informant to give reaction from their perspective and situation toward the data the researcher had organized. 
The study used source triangulation and theory triangulation. Source triangulation in the study was using data obtained from in-depth interview, FGD, observation data, and document. Theory triangulation in the study was conducted by reviewing the data resulted by using the appropriate theory.

The study used in the study was dependability audit. The researcher conducted auditing with the adviser of the study. As an auditor, the adviser would review the utilization of all data in the analysis, the researcher's subjectivity influence, the discovery of positive and negative cases, and barriers of the study.

\section{Data Processing and Analysis}

The study conducted data analysis by using content analysis. All data obtained from indepth interview and FGD were manually transcribed. And then coding was employed on each transcript. Subsequently, coding was grouped into categories. Each category, which was alike or unlike, was reviewed to determine the main category. All data, categories as the analysis result, discussion, and conclusion, afterward were reviewed for their validity by using triangulation and member check. The last stage was writing the final report.

\section{RESULTS}

\section{Characteristics of the Informants of the Study}

Characteristics of community in Semanggi Village including sex categories, age, religion, education and occupation were presented in Table 1. The result of characteristics of community in Semanggi Village showed the number of population in Semanggi Village in March 2017 was 9,213 heads of family with almost similar ratio between female and male that was 17,536 female $(49.7 \%)$ and 17,750 male (50.3\%). Based on religion, the characteristics of the community in Semanggi Village were Islam 31,019 people (87.9\%), Protestant 2,550 people (7.2\%), Catholic 1,688 people (4.8\%), Hindu 24 people (o.8\%), Confucianism 5 people (0.02\%) and zero population for Buddhist (о\%).

Based on age groups, the characteristics of community in Semanggi Village were as follow: 0-19 years 13,194 people (37.4\%), 20-39 years 11,603 people (32.9\%), 40-59 years 8,162 people (23.1\%) 60 years and over 2,327 people (6.6\%).

Most of the population in Semanggi Village were High School graduates (26.5\%), Junior High School graduates (22.4\%), Elementary School students 5,368 people (17.7\%), University graduates 3,211 jiwa (10.6\%), Finish Elementary School 1,936 people (6.4\%), not finish Elementary School (10.1\%), and never attended school (6.3\%).

Most of the population did odd jobs for living with occupation proportion of miscellaneous category was $51.3 \%$. In addition, the rest of the population in Semanggi Village worked as merchant (15.5\%), industrial labor (12.8\%), construction labor (10.3\%), people transportation (5.7\%), entrepreneur (2.5\%), Civil Servant/ Armed Force/ Police officers (0.9\%), retirement (0.9\%), and farmer (0.1\%).

Informants of the study consisted of 16 people, including 10 female and 6 male. All informants came from the same ethnic group which was Java. The age ranged from 30-70 years. The informants' occupation consisted of 7 homemakers, 2 retirements, 2 merchants, 4 labors, and 1 civil servant. 
Table 1. Characteristics of Community in Semanggi Village

\begin{tabular}{llcc}
\hline \multicolumn{1}{c}{ Characteristics } & \multicolumn{1}{c}{ Criteria } & $\mathbf{n}$ & $\mathbf{\%}$ \\
\hline Sex Categories & Male & 17,750 & 50.3 \\
Religion & Female & 17,536 & 49.7 \\
& Islam & 31,019 & 87.9 \\
& Protestant & 2,550 & 7.2 \\
& Catholic & 1,688 & 4.8 \\
Age & Hindu & 24 & 0.8 \\
& Confucianism & 5 & 0.02 \\
& O-19 years & 13,194 & 37.4 \\
Education & 20-39 years & 11,603 & 32.9 \\
& 40-59 years & 8,162 & 23.1 \\
& $\geq 60$ years & 2,327 & 6.6 \\
& Finish High School & 8,053 & $26.5 \%$ \\
& Finish Junior High School & 6,820 & $22.4 \%$ \\
& Finish University & 3,211 & $10.6 \%$ \\
& Still in Elementary School & 5,368 & 17.7 \\
& Not Finish Elementary School & 3,082 & 10.1 \\
& Never attend school & 1,922 & 6.3 \\
& Unemployed & 6 & 4.6 \\
& Student/University Students & 23 & 17.6 \\
& Civil Servant & 12 & 9.2 \\
& Private Employee & 26 & 20 \\
& Self Employed & 9 & 6.9 \\
& Farmer & 4 & 3 \\
& Labor & 3 & 2.3 \\
& Homemaker & 29 & 22.3 \\
& Civil Servant/ Armed Force & 18 & 13.8 \\
\hline & Retirement & &
\end{tabular}

2. Condition of Access to Water and Sanitation in Semanggi Village before Sanitation Kampung Program

\section{a) Limited Access to Clean Water}

People of Semanggi Village especially in RW 23 had lacked access to feasible water and sanitation. Some inhabitants' houses were equipped with well, however water was no longer feasible to consume. Therefore, for daily water consumption they bought water from inhabitants who had connected to PDAM pipelines.

"We cannot use the water from the well, since it is salty and yellowish. It seems clear at first, but will turn yellowish after it steady down. The area used to be iron market, there was a field for buses. When it rained the water went down the soil and carried iron substance that made the water yellow." ( I 2,I 3)

"Before IUWASH we asked around for water, well it was more like buying from our neighbors for daily cooking and drink. Our neighbors were okay with it, no problem, but they paid for the water bill, that made me uneasy, even though some of us gave a little money for it. It was Rp.20o-Rp.25O for each pail. We used water from the water pump for bathing and washing." (I 1) 
Journal of Health Promotion and Behavior (2017), 2(3): 257-271

https://doi.org/thejhpb.2016.02.03.06

In 1980 s the community leaders and the community members had an initiative to overcome water and sanitation problems by self-support building public bathing/ toilet, and it was accomplished in 1990 s.

"In 1980 we had plan to make the people here more civilized, excuse me, I mean to make them stop defecating at random places. We finally found a solution, we and our community leaders collected contribution Rp.5oo from each family as the initial fund for building public toilets on the east side." (I 13)

"We have had public toilet since 1991, it is under renovation at the moment. We used to go to public toilet to buy water for drinking, since we did not use water from the well for it." $\left(I_{3}, I_{7}\right)$

\section{a) The Lack of Access to Sanitation}

In addition to problem on clean water, people in Semanggi Village also lacked access to latrine. Most people did not have latrine, only one or two houses equipped with latrine. Therefore, most of the people in Semanggi Village defecated in public toilets that were limited in number or in random places in Bengawan Solo river.

"It was difficult for us to defecate, we should go to the river, things like that. I mean back then, it was only 1-2 people that had it at home." (I 4)

"Well, back then we didn't know what Kampung Sanitasi was. Since the first time living in $R W 23$ in 1980, it was such a primitive. In term of everybody, men, women, young and old, all of them defecated in Bengawan Solo river." (I 13)

"Since our community was still familiar with defecating in river, therefore even though we already had self-support public toilet, it was still not easy to change the habit. It took time and consistent sociallization."(I 8)
"The self-support public toilet could not accommodate us, therefore we went to dike, river." (I 14)

\section{b) Water and Sanitation was Priority} Issues in Semanggi Village

The condition of limited access to clean water and sanitation which was not feasible for long, was believed to be priority issue to overcome. The community leaders of RW23 Kelurahan Semanggi, then communicate the issue with the government to prioritize Semanggi Village for any aid related to sanitation and water.

"It is a priority, Ms. Instead of defecating in the gutter hehehe. Back then, a lot of kids pooped on the gutter. Priority, sanitation is priority." (I 5)

"As community leaders we gathered the people, community leaders and we had people in the legislative we could talk to and request, if anyone wanted to help for the community health of Semangi especially in RW23, we would welcome with open arms." (I 14)

3. Community's Perception toward Sanitation Kampung in Semanggi Village.

a) The Planning Process of Water and Sanitation

Facilities in Semanggi Village Surakarta Municipality Government and IUWASH planned the development of water and sanitation facilities in Semanggi Village in 2013 through Sanitation Kampung Program. At the beginning of Sanitation Kampung Program planning there were some pros and cons from the community. Some of the community accepted the program but some others refused it due to negative perception that Sanitation Kampung Program would cause bad smell and pollute well water.

"Most of us directly accepted, Ms. the people here just follow Pak RT and Pak $R W$. (I 4 ) 
Putri et al./ Community Participation in Sanitation

"There were a lot of people who refused it. They posted banners for it and there were 45 people who signed the refusal statement. They refused it with a reason that it would pollute the wells, especially around the location of public toilet." ( I 8, I 14)

"Once, there was a big waste water treatment here. The management made a dike that spilt to the river, therefore it produced unpleasant smell. People had a perception that the program would also produce unpleasant smell." (I 13)

Surakarta Municipality Government, IUWASH and the community leaders collaborated to overcome the refusal toward Sanitation Kampung Program by conducting socialization, society approach, as well as comparative study to other regions so that finally they accepted Sanitation Kampung Program in Semanggi Village.

"So, they kept on making an approach toward the people here. They took us to other regions, Jogja, Magelang, to see Sanitation Kampung there, for." (I 14).

"We, community leaders along with IUWASH convinced the community that it won't happen, since the program would be handled by the experts, so it won't leak through the well. Yet, there were still pros and cons. Finally, Mr. Mayor invited Pak $R T$ and the people to the city hall. Mr. Mayor gave us instructions. And with the instruction we came to an agreement." (I14)

"And IUWASH also needed working partner that was LPTP. And LPTP also formed another partner called KSM that came from the surrounding community, under the command of Pak RT. And finally, the public toilet program could be accomplished." (I 8)

\section{b) Development of Water and Sani- tation}

Facilities, Sanitation Kampung Program Despite the socialization and community approach that had been conducted, there were still some of community members who still rejected water facilities and latrine at their homes. The construction of water and sanitation facilities was conducted by some technician from LPTP. Several community members helped them, even only a few. In the middle of the construction process there were still cons and pros among members of community, therefore it took 1 year to complete the construction of water and sanitation facilities.

"People were different. There were more than 3 people who rejected the facilities of Sanitation Kampung Program. After we had completed the installing process, those people regretted it." (I 14)

"Those who obtained water facilities did not necessarily get latrine facilities, whereas those who obtained latrine facilities, must get water facilities. Since the latrine was related to the soil condition, tilt level. If the ground was lower than public toilet, latrine could not be put there, because all latrine would flow out to the public toilet." (I 8)

"Back then, IUWASH hand over the construction process to LPTP therefore community and KSM only watched over the process, whereas the construction was conducted all by outside workers. However, there were some members of community who helped a bit $\left(I_{3}, I_{5}, I_{11}\right)$.

"The construction was almost stopped. The digging out process was kept on interrupted. There was demonstration, so it was halted for almost 4 months. And it began again for more than 1 year. So it took more than 1 year to complete from the beginning to end. Finally it was completed." ( I 5). 


\section{Community Participation in Sani- tation Kampung Program in Se- manggi Village}

a) The utilization of water and sanitation facilities of Sanitation Kampung Program

Members of community utilized water and sanitation facilities from Sanitation Kampung Program for daily activities whereas members of community who did not get water and sanitation facilities, utilized public toilet to fulfill their need for water and daily activities.

"Yes, if we don't have water...I myself don't have well, if we don't have tap water either it will be troublesome. I could use it for bathing, washing the dishes, cooking, washing the clothes. For those who have water pump, the tap water is only for drinking." (I7, I9, I 11)

"The facilities help us in defecating. It used to be difficult. There was only one there, we had to queue, it would be annoying if we had to go and could not hold any longer. It helps us." (I 1, I 10)

b) The maintenance of water and sanitation facilities of Sanitation Kampung Program in each house

Members of communities conducted maintenance of water and latrine facilities in individual as well as collective setting. Latrine facilities maintenance at home was conducted by flushing with hot water, which was coordinated by KSM once every 2-3 months. Several members of community also conducted individual latrine flushing at home once every 2 weeks or 1 month or anytime it seemed smelly.

"It is once every 2 weeks or 1 month. It is by flushing with hot water so that the feces that sticks can get all flushed away. That's the instruction. " (I 2,I 4)

"If it gets smelly, I will boil a pot of water and flush it away. If it doesn't, then I will not. I will flush again if there is collective flushing once every 3 weeks, that's okay. It is for killing the germs and for the children's health. (I 6)

"Maintenance by flushing should be conducted together, collectively. So, KSM will tell the people that there will be voluntary work and for example at 9 we will flush simultaneously." ( I 1O)

Public toilet hygiene is the responsibility of 2 toilet keepers, who was on duty alternately. Toilet users paid the appropriate fare to the toilet keepers. Some of the money collected was given to KSM and the rest was the right of the toilet keepers. KSM managed the fund for community's social activities contribution and for reserve fund to anticipate damage on water and sanitation facilities

"There are two caretakers of toilet, who work alternately. If we think it is not clean enough, we ask the caretaker to clean it." (I 3, I 11)

"We give contribution to $R W$ and each RT for their program, even it is only 1 million per year. The remains is used to anticipate the damages, and for anything else we always have deposit fund." (I 14)

"Yes, Ms. Later at 4, I will scrub the toilet. Or else it will be very dirty. If somebody pay more, I always give the change. I always give Rp.15,0oo. And buy bathroom cleaner liquid Rp.6o,ooo per month. I always clean it regularly, it's true, Ms." (I 12)

\section{c) Damages on Water and Sanitation Facilities in Sanitation Kampung Program}

Since the first time it was used, water and sanitation facilities still functioned well. Some people found their water meter damaged. It was because water meter was not covered and exposed to rain and direct sunlight and then it got weathered. In addition, initially the public toilet used well, and once it got dry. The well was made during 
rainy season, therefore it got dry in dry season.

"Praise the Lord, it is not broken, and hopefully it won't be broken ever." (I 1, I 4, I 6)

"The water meter is easily broken. IUWASH can help, but it is put in front the house, it gets exposed to sunlight and rain and gets weathered. They offered us the lid, but we refused it since we had to pay for it."

If there was any damages on water and sanitation facilities, people would tell KSM officers, who would repair it. If the damages were beyond KSM capacity to repair, KSM would report it to PDAM for the replacement.

"Yes, I asked for the replacement, later I just need to pay for it. I replace it myself, Mr.Drajat helped me." (I 9)

"So, one of us joined a training on it. We were taught the maintenance and cleanliness, from PU through IUWASH. We completed the training. Therefore we can work by ourselves now after IUWASH and LPTP let loose us, it was because of the training." (I 14)

\section{Government's Role toward Sani- tation Problem in Semanggi Village} Since 2016 Surakarta Health Office launched STBM Program for all villages in Surakarta through Puskesmas in Surakarta area. In the area of Semanggi Village, STBM Program would be organized in RW17 since there were still people who defecating in the open air. Open defecation was conducted because there was no land for septic tank. By STBM Program it was expected that people initiated to self- procure a location for feasible public toilet.

"This year a sanitation-related program from Puskesmas is started to promote in all villages. In Semanggi Village, STBM program will be organized in around August 2017, in $R W 17$ noyt $R W 23$, since there were people defecate in the open air. What it is meant by open defecation is not like defecating on the river. They do not do it anymore. Instead, they have already had the public toilet, however they don't have the septic tank yet since there is no land for it. STBM program is implemented with a trigger, by which it is expected the people willing to build feasible toilet by themselves." (I 16)

\section{Accomplishment and Barriers of Sanitation Kampung Program in Semanggi Village}

People thought that Sanitation Kampung Program has successfully proceeding. Members of community felt satisfied toward the occurrence of Sanitation Kampung Program in Semanggi Village. Water and sanitation facilities of Sanitation Kampung program had improved the condition of what so called slum. However, community leaders were not yet satisfied since there were a lot of members of community who had not received water and sanitation facilities in Semanggi Village.

"Yes, it is accomplished. The water runs well, the toilet is used by people nearby, it seems truly beneficial. We used to be labeled as red kampong, slum. But now, it turns good with the program." (I2, I 7, I 11)

"Well, from my perspective it is not yet, Ms.Since not all members of community can feel it, only a part of it. The facility is not yet able to be improved. It should be expanded, if it is possible." ( I 13)

After water and sanitation facilities was available, the health condition of people of Semanggi village was improved. Before Sanitation Kampung Program, people often suffered from diarrhea, itchy, and dengue fever.

"Defecating on the river is very susceptible for diseases. Our community used to suffer from diarrhea and itchy. Praise 
Journal of Health Promotion and Behavior (2017), 2(3): 257-271

https://doi.org/thejhpb.2016.02.03.06

the Lord, after the program from IUWASH the health condition is getting improved. The diseases are reduced. Moreover, dengue fever used to strike every month. There were 23 people all over $R W$, now it is reducing." (I $6, I 8, I 14)$

\section{Community Expectation toward the Condition of Water and Sanita- tion Facilities in Semanggi Village}

Community expected Sanitation Kampung Program would still proceed well and be more organized also neat. Furthermore, members of community also expected there would be more people who received water and sanitation facilities at their house. Another expectation was economy and education development.

"If it is possible, make it better. There's nothing here. The bathroom needs latrine. And make it cleaner, build walls. That's what I want. Make it better, that's it." (I 9)

"In the future we truly expect for not only sanitation, but also drainage, renovation of damaged road and economy also education development." (I 5, I 8)

\section{DISCUSSION \\ The character of community in Semanggi Village with high population density and low level of education and economy en- couraged the limited access to water and sa- nitation in Semanggi Village. High popu- lation density lead to unavailability of land to build feasible water and sanitation faci- lities.}

According to a study by Mazaya (2016) the habit of open defecation is influenced by social condition such as educational background, occupation, and poverty factor. Low level of education generates community's lack of awareness to conduct clean and healthy behavior. Likewise, low level of economy instigates people unable to build themselves feasible water and sanitation facilities (Akter and Ali, 2013). Undrinkable well water is generated by contaminated shallow ground water. A study by Mahanani et al., (2015) showed that most inhabitants' wellsin Pasar Kliwon Sub-district region are categorized as shallow well that is easy to get contaminated.

Even though community in Semanggi Village needed aid for water and sanitation facilities however with characteristics of low economy and educational background, they found it uneasy to accept Sanitation Kampung Program. There were pros and cons during planning and building water and sanitation facilities of Sanitation Kampung Program. The occurrence of pros and cons among the community represented the occurrence of community's negative perception and positive perception toward Sanitation Kampung Program. Social perception in the program is an important matter that may influence sanitation behavior change (Novotny et al., 2017).

Positive perception toward Sanitation Kampung Program was encouraged by the intention to obtain water and sanitation facilities which were feasible, safe and comfortable, as well as the confidence toward the leaders who wanted to accept the program, therefore the members of community willing to follow the leader who has accepted the program. Meanwhile, community's negative perception toward Sanitation Kampung Program was generated by negative experience related to waste disposal that produced unpleasant odor, the feeling of worry for the impactof Sanitation Kampung Program that might contaminate the people's wells, the lack of awareness on the needs for feasible water and sanitation, distrust toward the leaders and their nature to follow role model community leaders who rejected Sanitation Kampung Program. 
To overcome community's negative perception toward a certain program it takes continuous program socialization. Program socialization may improve community's knowledge therefore it is able to eliminate negative impact perception that Sanitation Kampung Program produces odor and contamination and improve people's awareness on the needs for feasible water and sanitation facilities. Perception of unpleasant odor may turn to strategy in sanitation program promotion and planning (Rheinlander et al., 2013). Socialization in the form of one way coaching is often ineffective for information receivers with low education level. Comparative study of members of community and community leaders give influence in improving people's support. By observing the actual evidence of water and sanitation facilities in other region that did not generate odor and contamination, might improve people's confidence toward Sanitation Kampung Program.

In addition to socialization and comparative study, the approach and communication of bureaucrats, community leaders and members of community in Semanngi Village also played an important role to improve community's confidence toward community leaders, help in understanding community condition and seek for solution for the problems occur in the community. Through socialization process, comparative study and community leaders' approach, the community finally accepted and supported the implementation of Sanitation Kampung Program in Semanggi Village.

Members of community were participating by helping and monitoring the construction of water and sanitation facilities. Participation of members of community in the process of Sanitation Kampung Program construction was able to increase the community's sense of belonging and responsibility toward Sanitation Kamping Program so that it can support the community's continuous participation toward Sanitation kampong Program.

Community's participation was seen from the utilization and maintenance of water and sanitation facilities. Water facilities, latrine and public toilet were beneficial for people's daily needs. Sanitation program may improve public health and improve health behavior (WSP,2013). Water and sanitation facilities improve the people's limited access to water and sanitation and improve public health in Semanggi Village. Participation in water and sanitation facilities maintenance is an important matter to ensure the sustainable water and sanitation facility. Community participation may support the program implementation and sustainability in rural area (Sulaeman et al., 2015).

Latrine maintenance by members of community was in accordance with IUWASH instructions. People who perform communal latrine maintenance independently, collectively, and regularly represented that community had participated in sanitation maintenance. Latrine maintenance activities with in collaboration KSM management represented that sanitation maintenance still needed KSM and community leaders support to coordinate the activities collectively. Management organization, and collaboration with community members is an important matter for the program sustainability and asset preservation (Sapei et al., 2011).

Water maintenance was performed by members of community by paying water bill to PDAM. It was important to keep the water access in Semanggi Village maintained. Financial management can support the sustainability of water and sanitation facilities (Olayujigbe, 2016). In addition, water maintenance was also performed by 
civil society groups trained by IUWASH in operating and maintaining water and sanitation facilities. Therefore, in maintaining water and sanitation facilities it needed collaboration among members of community, community leaders, and KSM. Committee for health and sanitation in village level has important function in the planning and action of public health (Srivastava et al., 2013).

Public toilet maintenance was performed by the toilet keepers and it was people's responsibility as the users of public toilet facilities to pay as the fare. It represented that in term of maintenance of toilet hygiene people still did not have awareness to do it independently. It is in accordance with a study by Simiyu et al., (2017) that showed the hygiene condition of public sanitation facilities is influenced by the number of people who use the facilities as well as the people's awareness.

The visits from municipality government, and regional representative council, government aids as well as Sanitation Kampung Program in Semanggi Village represented that government prioritized the era in Semanggi Village in improving water and sanitation access. The involvement of Surakarta Mayor in overcoming the rejections of community members toward Sanitation Kampung Program represented the government support in the implementation of Sanitation Kampung Program. Government has important role in ensuring the implementation of sanitation program, financial assistance, and cross sectoral collaboration to overcome santitaion problems (Mara et al., 2010).

Referring to the purpose of Sanitation Kampung Program to give model for clean water supply and community based sanitation development in Indonesia, therefore Sanitation Kampung Program could be considered as accomplished. It is explained from the result of the study that members of community considered that Sanitation Kampung Program accomplished in helping people to obtain water and sanitation more easily. In addition, participation of community members supported the accomplishment of Sanitation Kampung Program. The study result of several KSMs from other regions that conducted comparative study in Semanngi Village also showed that Sanitation Kampung Program had successfully turned to be a model of feasible water and sanitation provison.

Despite the accomplishment, community members and leaders in Semanggi Village still have an expectation that all houses in Semanggi Village can benefits from sanitation and water facilities as well as infrastructures improvement in Semanggi Village.

\section{REFERENCE}

Akter T, Ali AM (2013). Factors influencing knowledge and practice of hygiene in Water, Sanitation and Hygiene (WASH) programme areas of Bangladesh Rural Advancement Committee. Rural and Remote Heath 14: 1-10.

Cairncross S, Hunt C, Boisson S, Bostoen K, Curtis V, Fung ICH, dan Schmidt WP (2010). Water, sanitation and hygiene for the prevention of diarrhoea. International Journal of Epidemiology 39: 193-205.

Dinas Kesehatan Jawa Tengah (2014). Profil Kesehatan Provinsi Jawa Tengah Tahun 2014. Semarang: Dinkes Jateng.

Echazú A, Bonanno D, Juarez M, Cajal SP, Heredia, V, Caropresi S, Cimino RO, Caro N, Vargas PA, Paredes G, dan Krolewiecki AJ (2015). Effect of Poor Access to Water and Sanitation As Risk Factors for Soil-Transmitted Helminth Infection: Selectiveness by 
the Infective Route. Plos One 9(9): 114.

Engel S, Susilo A (2014). Shaming and Sanitation in Indonesia: A Return to Colonial Public Health Practices. Development and Change 45(1): 157178.

Enralin J, Lubis RH (2015). Akses Air Bersih dan Sanitasi Layak pada Masyarakat Permukiman Kumuh Perkotaan. lib.ui.ac.id.

Gon G, Méndez MCR, Campbell OMR, Barros AJD, Wood S, Benova I, dan Graham WJ (2016). Who Delivers Without Water? A Multi Country Analysis of Water and Sanitation in the Childbirth Environment, Plos One, 11(8): 1-19.

Indonesia Urban Water Sanitation and Hygiene (IUWASH) (2014). USAID Indonesia Urban Water Sanitation and Hygiene Performance Monitoring Plan (PMP) Third Revision, www.iuwash.or.id, Diakses 7 Novemer 2016.

Jeuland MA, Fuente DE, Ozdemir S., Allaire MC, dan Whittingtonm D (2013). The Long-Term Dynamics of Mortality Benefits from Improved Water and Sanitation in Less Developed Countries, Plos One 8(10): 1-17.

Kasnodihardjo, Elsi E (2013). Deskripsi Sanitasi Lingkungan, Perilaku Ibu, dan Kesehatan Anak, Jurnal Kesehatan Masyarakat Nasional, 7(9): 415420.

Kementerian Kesehatan RI (Kemenkes RI) (2011). Laporan Nasional: Riset Kesehatan Dasar (Riskesdas) 2010, Jakarta: Badan Penelitian dan Pengembangan Kesehatan Kementerian Kesehatan.

(2013). Riset Kesehatan Dasar 2013.

Mahanani YD, Koosdaryani, Sulastoro (2015). Analisis Konstruksi Sumur yang Mempengaruhi Munculnya Bakteri Coli Pada Kecamaatan Pasar Kliwon Kota Surakarta. e-Journal Matriks Teknik Sipil, 81-88.

Mara D, sLane J, Scott B, Trouba D (2010). Sanitation and Health. PLoS Med 7 (11):1-7.

Mengel MA (2014). Cholera in Africa: New Momentum in Fighting an Old Problem, Royal Society of Tropical Medicine and Hygiene, 108: 391-392.

Novotny J, Kolomazníková J, Humnalová H (2017). The Role of Perceived Social Norms in Rural Sanitation: An Explorative Study from InfrastructureRestricted Settings of South Ethiopia. International Journal of Environment Research and Public Health 14(794): 1-17.

Olajuyigbe AE (2016). Community Participation and Sustainability Issue: An Evaluation of a Donor-Driven Water Sector in Ikaram Millennium Village Project, Nigeria. Open Journal of Social Sciences 4:90-103.

Rheinlander T, Keraita B, Konradsen F, Samuelsen H, Dalsgaard A (2013). Smell: an overlooked factor in sanitation promotion. Waterlines 32(2): 106-112.

Sapei A, Purwanto MYJ, Sutoyo, Kurniawan A (2011). Perencanaan Instalasi Pengolahan Air Limbah Sistem Komunal Berbasis Masyarakat (Studi Kasus Kelurahan Putat, Kecamatan Tanggulangin Sidoarjo). Jurnal Ilmu Pertanian Indonesia 16(2): 91-99.

Simiyu S, Swilling M, Cairncross S, Rheingans R (2017). Determinants of quality of shared sanitation facilities in informal settlements: case study of Kisumu, Kenya. BMC Public Health 17 (68): 1-13.

Sofyan I, Soewondo P, Kunaefi TD, dan Handajani M (2016). Community- 
Journal of Health Promotion and Behavior (2017), 2(3): 257-271

https://doi.org/thejhpb.2016.02.03.06

Managed Decentralized Sanitation In The Greater Bandung Slum Areas. Asian Journal of Water Environment 3(1): 14-31.

Srivastava A, Gope R, Nair N, Rath S, Rath S, Sinha R, Sahoo P, Biswal PM, Singh V, Nath V, Sachdev HPS, Worrall JS, Bidgoli HH, Costello A, Prost A, Bhattacharyya S (2016). Are village health sanitation and nutrition committees fulfilling their roles for decentralised health planning and action? A mixed methods study from rural eastern India. BMC Public Health 16(59): 1-12.

Sulaeman ES, Murti B, Waryana (2015). Peran Kepemimpinan, Modal Sosial, Akses Informasi serta Petugas dan Fasilitator Kesehatan dalam Pemberdayaan Masyarakat Bidang Kesehatan. Jurnal Kesehatan Masyarakat Nasional 9(4): 353-361.
Taylor DL, Kahawita TM, Cairncross S, dan Ensink JHJ (2015). The Impact of Water, Sanitation and Hygiene Interventions to Control Cholera: A Systematic Review, Plos One, 10(8): 1-19.

Trisnawati A, Marsono BD (2012). Evaluasi Program Sanitasi Berbasis Masyarakat (SANIMAS) di Kota Kediri, ITS Surabaya: Scientific Conference of Environmental Technology IX.

UNICEF (2012). Air Bersih, Sanitasi \& Kebersihan. UNICEF Indonesia.

Water and Sanitation Program (WSP) (2013). Scaling Up Rural Sanitation Impact Evaluation of a Large-Scale Rural Sanitation Project in Indonesia.

World Health Organization (WHO) (2015). From MDGs to SDGs: General Introduction. 